\title{
Possible Regulation of bFGF Expression by Mast Cells in Osteoarthritis Patients with Obesity: A Cross-Sectional Study
}

\author{
Ken Takata \\ Kentaro Uchida (D) \\ Shotaro Takano \\ Manabu Mukai \\ Gen Inoue (D) \\ Hiroyuki Sekiguchi \\ Jun Aikawa \\ Masayuki Miyagi \\ Dai Iwase \\ Masashi Takaso
}

Department of Orthopedic Surgery, Kitasato University School of Medicine, Sagamihara City, Kanagawa, 252-0374, Japan
Correspondence: Kentaro Uchida Department of Orthopedic Surgery, Kitasato University School of Medicine, I-I5-I Minami-Ku Kitasato, Sagamihara City, Kanagawa, 252-0374, Japan $\mathrm{Tel} / \mathrm{Fax}+8 \mathrm{I}-042-778-9217$

Email kuchida@med.kitasato-u.ac.jp
Purpose: Obesity is associated with the risk of developing knee osteoarthritis (KOA). Furthermore, synovial basic fibroblast growth factor (bFGF) is linked to the severity of KOA. We previously demonstrated that bFGF and mast cell (MC) marker expression were elevated in the synovial tissues (ST) of KOA patients with obesity. However, it remains unclear whether MCs contribute to bFGF expression and regulation.

Patients and Methods: Radiographically diagnosed KOA patients ( $\mathrm{n}=249)$ were assigned to groups based on the body mass index (BMI) classifications used by the World Health Organization: normal-weight ( $\mathrm{NW}, \mathrm{BMI}<25 \mathrm{~kg} / \mathrm{m}^{2}, \mathrm{n}=95$ ), overweight (OW, BMI $\geq 25$ and $<30, \mathrm{n}=109)$ and obese $\left(\mathrm{OB}, \geq 30 \mathrm{~kg} / \mathrm{m}^{2}, \mathrm{n}=45\right) . B F G F$ expression in the ST was examined using quantitative polymerase chain reaction and compared across the BMI groups. Additionally, $B F G F$ and interleukin (IL) 13 expression were examined in freshly extracted MC-rich (THY-1-, CD3-, CD14-, and CD19-) and MC-poor (THY-1+, CD3+, CD14+, or $\mathrm{CD} 19+)$ fractions from ST. Moreover, regulation of $B F G F$ expression by IL-13 was studied in CD14-negative (fibroblast-rich) and CD14-positive (M $\varphi$-rich) and cells in culture.

Results: $B F G F$ expression was significantly higher in $\mathrm{OB}$ than in NW patients. Furthermore, although IL13 was significantly higher in the MC-rich than the MC-poor fraction, $B F G F$ expression was comparable. Recombinant human IL-13 stimulated expression of $B F G F$ in synovial fibroblast cells.

Conclusion: $B F G F$ expression is higher in the ST of KOA patients with obesity. Increased numbers of MCs may contribute to the elevated BFGF expression through IL-13 in KOA patients with obesity.

Keywords: obesity, mast cell, osteoarthritis, $B F G F$, IL13, synovial tissues

\section{Introduction}

Obesity has been shown to increase the prevalence and development of osteoarthritis (OA) in weight-bearing as well as non-weight-bearing joints. ${ }^{1,2}$ This suggests that other factors apart from mechanical loading may explain the association between obesity and OA. Such other factors may also contribute to OA pathology. However, these factors remain elusive.

Basic fibroblast growth factor (bFGF) regulates cell proliferation and contributes to the matrix metalloproteinase production and breakdown of the extracellular matrix in articular cartilage. ${ }^{3}$ Furthermore, bFGF contributes to the pathology of joint destruction, ${ }^{4}$ with bFGF levels in synovial fluid having been shown to be associated with radiographic severity of knee OA $(\mathrm{KOA}) .^{5}$ In our previous report, 
we found that $B F G F$ mRNA expression was increased in the synovial tissues (ST) of KOA patients with obesity. ${ }^{6}$ However, the mechanisms underlying the rise in bFGF in patients with obesity remain unclear.

Mast cells (MCs) are present in the ST, and are elevated in patients with rheumatoid arthritis $(\mathrm{RA})^{7,8}$ and $\mathrm{OA},{ }^{9-11}$ where they are suggested to play a pivotal role in both acute and chronic inflammation. Recent evidence indicates a possible link between MCs and KOA severity. ${ }^{10}$ bFGF is among a range of growth factors generated by MCs under inflammatory conditions. ${ }^{12,13} \mathrm{We}$ previously reported that $B F G F$ expression was correlated with the MC marker expression. ${ }^{6}$ However, bFGF expression in MCs remains to be studied.

Interleukin (IL)-13 is an MC-secreted cytokine. ${ }^{14-16}$ Increased IL-13 levels are observed in the synovial fluid of patients with KOA and rheumatoid arthritis. ${ }^{17,18} \mathrm{IL}-13$ level in synovial fluid is correlated with OA pain and function. ${ }^{19}$ Interestingly, IL-13 has been shown to regulate bFGF in airway smooth muscle cells. ${ }^{20}$ We hypothesized that MCs express IL-13 and that IL-13 regulates bFGF in the ST of KOA patients.

We investigated $B F G F$ and $I L 13$ expressions in MCs, and the effect of IL-13 on $B F G F$ expression in KOA patients.

\section{Patients and Methods}

Total knee arthroplasty (TKA) was performed on all participating subjects at our hospital. A total of 249 ST specimens were harvested from patients diagnosed with radiographic KOA during TKA. A small section of each specimen was immediately frozen in liquid nitrogen and placed at $-80^{\circ} \mathrm{C}$ until RNA extraction. Specimens taken from 10 patients were subjected to experiments aimed at determining $B F G F$ expression in MCs, and samples taken from 8 patients to experiments aimed at examining whether IL-13 regulates $B F G F$ expression.

The study protocol received approval from Kitasato University Hospital institutional Ethics Review Board (approval number: KMEO B19-259). All participants provided written informed consent to participate and for removal of their synovial tissue the day prior to surgery. This study complied with the principles of the Declaration of Helsinki.

Patients were assigned to groups based on the body mass index (BMI) classifications used by the World Health Organization: normal-weight (BMI $<25 \mathrm{~kg} / \mathrm{m} 2, \mathrm{n}=95$ ), overweight (BMI $\geq 25$ and $<30, \mathrm{n}=109)$ and obese $(\geq 30 \mathrm{~kg} / \mathrm{m} 2$, $\mathrm{n}=45$ ). The patients' clinical characteristics are summarized in Table 1 by BMI group. MC marker (CD117, CD203c,
Table I Patients' Clinical Characteristics

\begin{tabular}{|l|c|c|c|c|}
\hline & $\begin{array}{c}\text { Normal } \\
(\mathbf{n = 9 5 )}\end{array}$ & $\begin{array}{c}\text { Overweight } \\
(\mathbf{n}=109)\end{array}$ & $\begin{array}{c}\text { Obese } \\
(\mathbf{n}=45)\end{array}$ & $\mathbf{P}$ \\
\hline Age (years) & $75.8 \pm 7.5$ & $73.2 \pm 6.9^{\mathrm{a}}$ & $71.1 \pm 7.4^{\mathrm{a}, \mathrm{b}}$ & $<0.001$ \\
Male/female, $\mathrm{n}$ & $17 / 78$ & $32 / 77$ & $7 / 38$ & 0.099 \\
$\mathrm{KL}(3 / 4), \mathrm{n}$ & $29 / 66$ & $31 / 78$ & $1 \mathrm{I} / 44$ & 0.634 \\
BMI $\left(\mathrm{kg} / \mathrm{m}^{2}\right)$ & $22.2 \pm 1.9$ & $27.2 \pm 1.4^{\mathrm{a}}$ & $32.8 \pm 2.2^{\mathrm{a}, \mathrm{b}}$ & $<0.001$ \\
\hline
\end{tabular}

Notes: Data are mean \pm standard deviation unless otherwise indicated. ${ }^{a}$ Statistical difference between normal and obese groups. "'Statistical difference between overweight and obese groups.

Abbreviations: KL, Kellgren and Lawrence grade; BMI, body mass index.

TPSB2 ( $\beta$-tryptase)) and $B F G F$ expression in the ST were compared across the BMI groups using RT-PCR.

\section{qPCR}

Details of RNA extraction, cDNA synthesis and qPCR using SYBR Green are published elsewhere. ${ }^{8,21}$ qPCR primer sequences are shown in Table 2. All gene expression was normalized to that of GAPDH.

\section{Expression of BFGF and ILI3 in MCs}

Cells isolated from synovial tissue were separated into MCrich and MC-poor fractions as described previously, ${ }^{21}$ and examined for $B F G F$ and $I L 13$ expression. To digest ST, samples were immediately immersed in collagenase solution at $37^{\circ} \mathrm{C}$ for $2 \mathrm{~h}$. Extracted cells reacted with the following antibodies for 30 minutes at $4^{\circ} \mathrm{C}$ : biotin-conjugated anti-THY-1 (fibroblast marker), anti-CD3 (T cell marker), anti-CD14 (M $\varphi$ marker), and anti-CD19 (B cell marker). The cells were subsequently washed twice with Hanks' balanced salt solution, and exposed to streptavidin-conjugated magnetic particles (BD Biosciences, CA, USA). A magnetic separation system (BD Biosciences) was used to separate the cells into negative (MC-rich; THY-1-, CD3-, CD14-, and CD19-) and positive (MC-poor; THY-1+, CD3+, CD14+, or CD19+) fractions. qPCR was used to determine the $B F G F$ and $I L 13$ expression in negative (MC-rich) and positive fractions.

\section{Effect of IL-I 3 on Synovial Fibroblasts and $M \varphi$}

Synovial fibroblasts and $\mathrm{M} \varphi$ were isolated from ST samples harvested from $8 \mathrm{KOA}$ patients to study the role of IL-13 in the synovium. CD14-positive (M $\varphi$-rich) and CD14-negative (fibroblast-rich) cells were separated using the magnetic separation technique described in a previous protocol. ${ }^{22}$ CD14-negative and CD14-positive cells were seeded in $\alpha$ MEM in six-well plates and cultured for 7 days. Thereafter, 
Table 2 Primer Sequences

\begin{tabular}{|l|l|l|l|}
\hline Gene & Direction & Primer sequence (5'-3') & Product size (bp) \\
\hline TPSB2 & $\mathrm{F}$ & $\begin{array}{l}\text { CGCAAAATACCACCTTGGCG } \\
\text { GTGCCATTCACCTTGCACAC }\end{array}$ & 138 \\
\hline ILI3 & $\mathrm{F}$ & $\begin{array}{l}\text { CCTCATGGCGCTTTTGTTGAC } \\
\text { TCTGGTTCTGGGTGATGTTGA }\end{array}$ & 134 \\
\hline CDII7 & $\mathrm{R}$ & $\begin{array}{l}\text { TGACTTACGACAGGCTCGTG } \\
\text { CCACTGGCAGTACAGAAGCA }\end{array}$ & 126 \\
\hline CD203C & $\mathrm{F}$ & $\begin{array}{l}\text { CGACTGCACTATGCCAAGAA } \\
\text { GGTCCATGTGCCAGAAAGAT }\end{array}$ & 164 \\
\hline BFGF & $\mathrm{F}$ & AGAGCGACCCTCACATCAAG \\
ACGGTTAGCACACACTCCTT & 80 \\
\hline GAPDH & $\mathrm{R}$ & $\mathrm{F}$ & 129 \\
\hline
\end{tabular}

the cells were exposed to vehicle (serum-free media) or 100 $\mathrm{ng} / \mathrm{mL}$ of recombinant human IL-13 (rh-IL13; BioLegend) for 6 hours. The IL-13 concentration was chosen based on a protocol reported previously. ${ }^{20}$ Following stimulation, qPCR was conducted to measure $B F G F$ expression.

\section{Statistical Analyses}

All analyses were conducted based on a pre-specified statistical analysis plan. All analyses were performed using SPSS 25.0. Continuous variables were compared between two groups using the Wilcoxon signed-rank test and among three groups using the Kruskal-Wallis test followed by the Mann-Whitney $U$-test using Bonferroni correction. Categorical variables were compared using the Fisher's exact test. $\mathrm{P}<0.05$ was indicative of statistical significance.

\section{Results}

\section{Clinical Characteristics by BMI}

OB patients were significantly younger than NW and OW patients (Table 1). The proportion of male to female patients $(\mathrm{P}=0.099)$ and those with Kellgren and Lawrence grade 3 and $4(\mathrm{P}=0.634)$ was comparable across the $\mathrm{BMI}$ groups (Table 1).

\section{Expression of Synovial MC Markers (CD I I 7, CD203c, TPSB2) and BFGF by BMI} OB patients had significantly higher levels of $C D 117$ than NW patients $(\mathrm{P}=0.011)$, while $\mathrm{NW}$ - and $\mathrm{OW}$ patients had comparable levels $(\mathrm{P}=0.535)$ (Figure $1 \mathrm{~A})$. OB patients also had significantly higher levels of $C D 203 c$ than NW patients $(\mathrm{P}=0.027)$ but comparable levels to $\mathrm{OW}$ patients $(\mathrm{P}=0.161)$ (Figure 1B). Likewise, OB patients had significantly higher levels of TPSB2 than NW patients $(\mathrm{P}=0.002)$ but comparable levels to $\mathrm{OW}$ patients ( $\mathrm{P}=0.247$ ) (Figure $1 \mathrm{C}$ ).

Similarly, OB patients had significantly higher levels of $B F G F$ expression than NW patients $(\mathrm{P}=0.020)$ but comparable levels to $\mathrm{OW}$ patients $(\mathrm{P}=0.283$ ) (Figure 1D).

\section{Correlation Between MC Markers and BFGF Expression}

Since our results indicated that KOA patients with obesity had higher expression levels of MC markers (CD117, CD203c, TPSB2) and $B F G F$, we next investigated the correlation between $\mathrm{MC}$ marker and $B F G F$ expression. $B F G F$ expression was significantly correlated with $C D 117(\rho=0.273, \mathrm{P}<0.001$; Figure 2A) $C D 203 c(\rho=0.432, \mathrm{P}<0.001$; Figure $2 \mathrm{~B})$ and TPSB2 $(\rho=0.164, \mathrm{P}<0.001$; Figure $2 \mathrm{C})$ levels.

\section{Markers, BFGF and ILI 3 in MCs}

Next, we measured the expression of $\mathrm{MC}$ markers (CD117, CD203c, TPSB2), BFGF and IL13 in MCs in $\mathrm{MC}$-rich and MC-poor fractions isolated from ST specimens of KOA patients. The MC-rich fraction expressed significantly higher levels of $\mathrm{MC}$ markers $(\mathrm{P}=0.005$; Figure $3 \mathrm{~A}-\mathrm{C})$ and $I L 13(\mathrm{P}=0.009$; Figure $3 \mathrm{D})$ than the $\mathrm{MC}$-poor fraction. Meanwhile, MC-rich and MC-poor fractions expressed comparable levels of $B F G F$ $(\mathrm{P}=0.285$; Figure $3 \mathrm{E})$. 
A

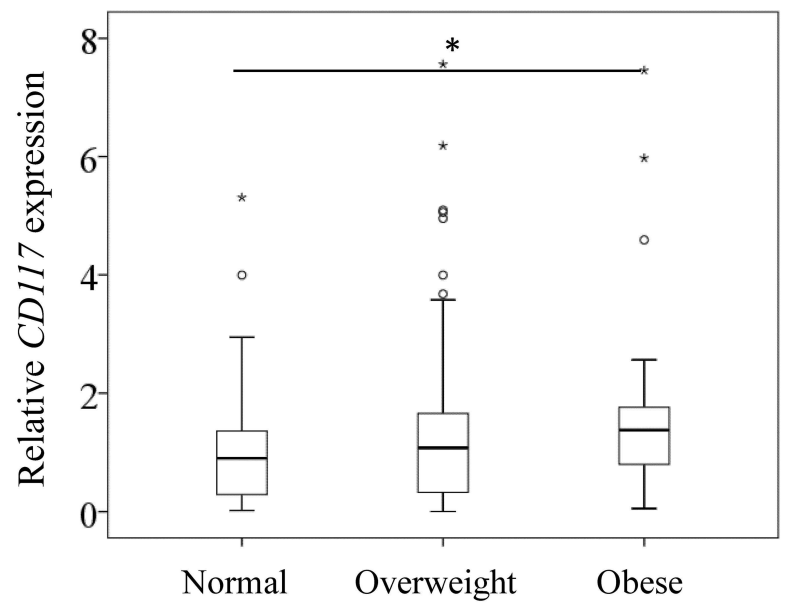

C

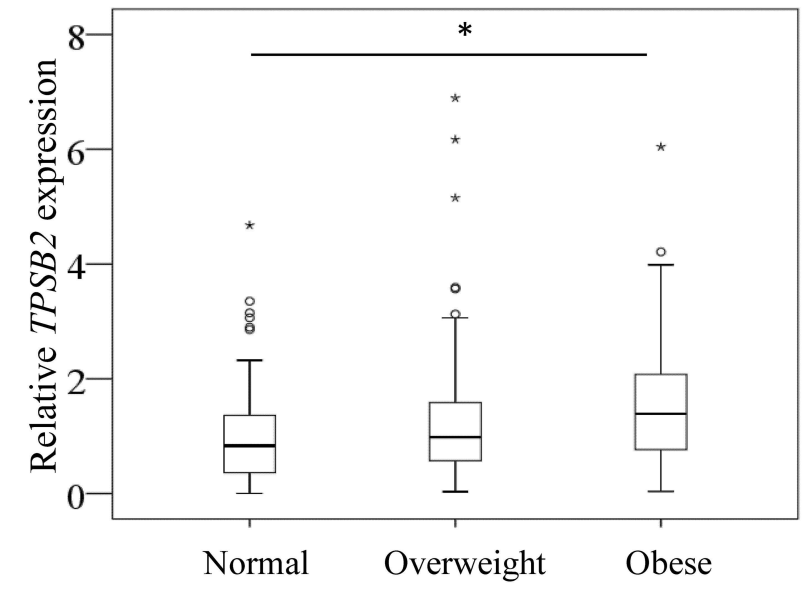

B

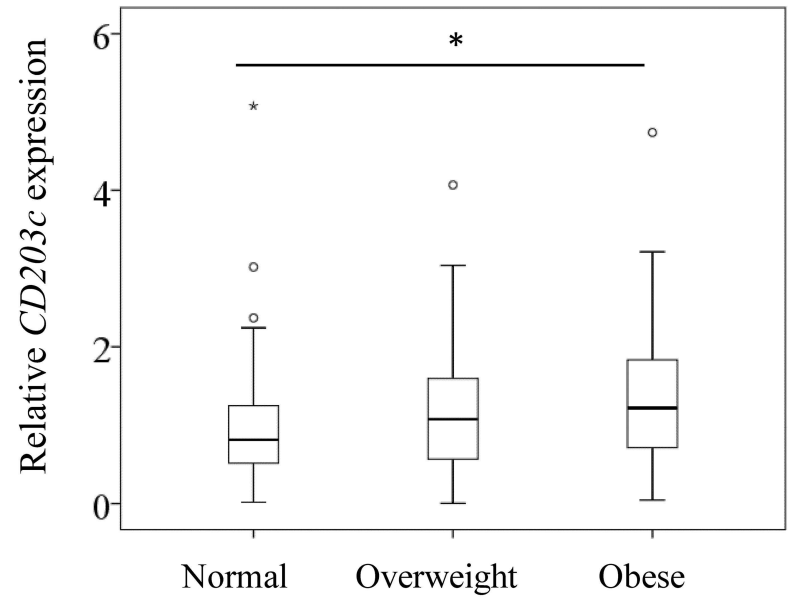

D

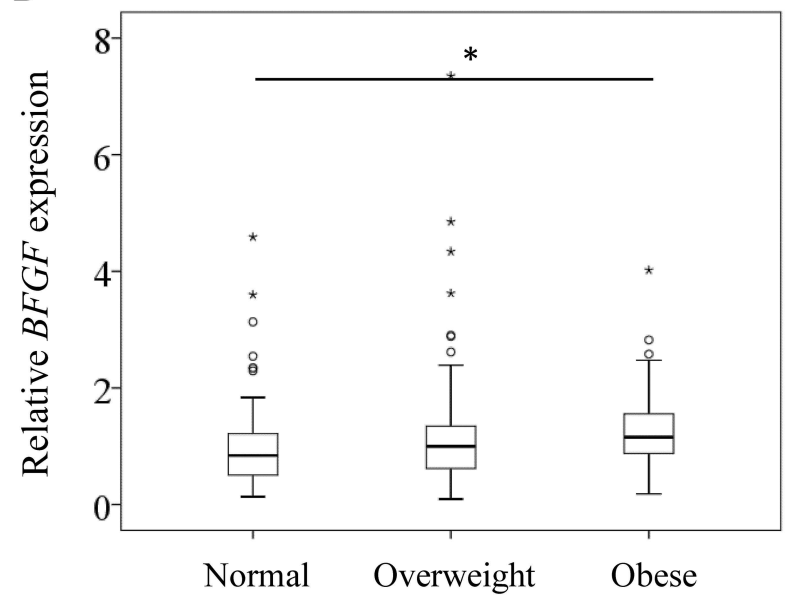

Figure I CD I I 7 (A), CD203c (B), TPSB2 (C), and BFGF (D) mRNA expression in the synovium of normal, overweight, and obese patients with knee osteoarthritis. *P<0.05. $P$ values are indicated.

A

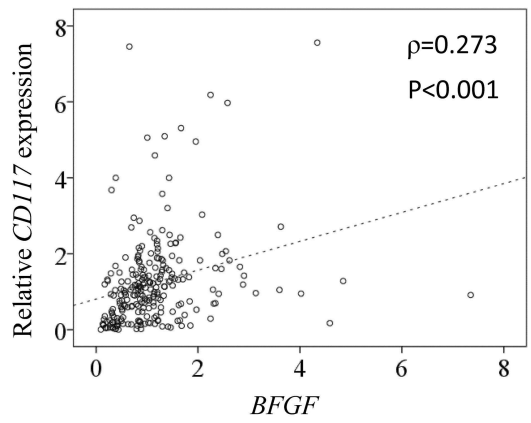

B

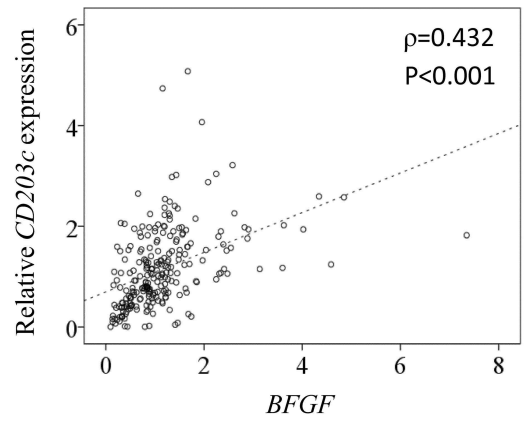

C

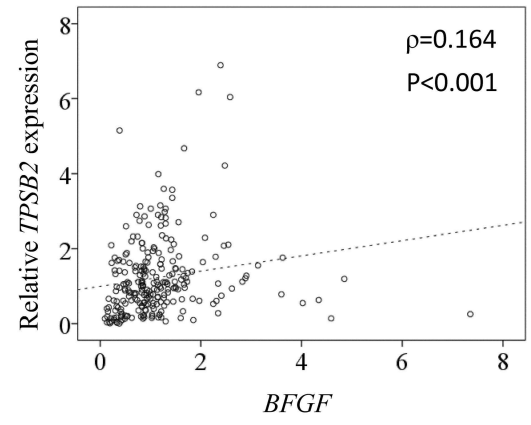

Figure 2 Correlation between expression of BFGF and MC markers. Correlation between expression of BFGF and CDI I7 (A), CD203c (B), and TPSB2 (C). 

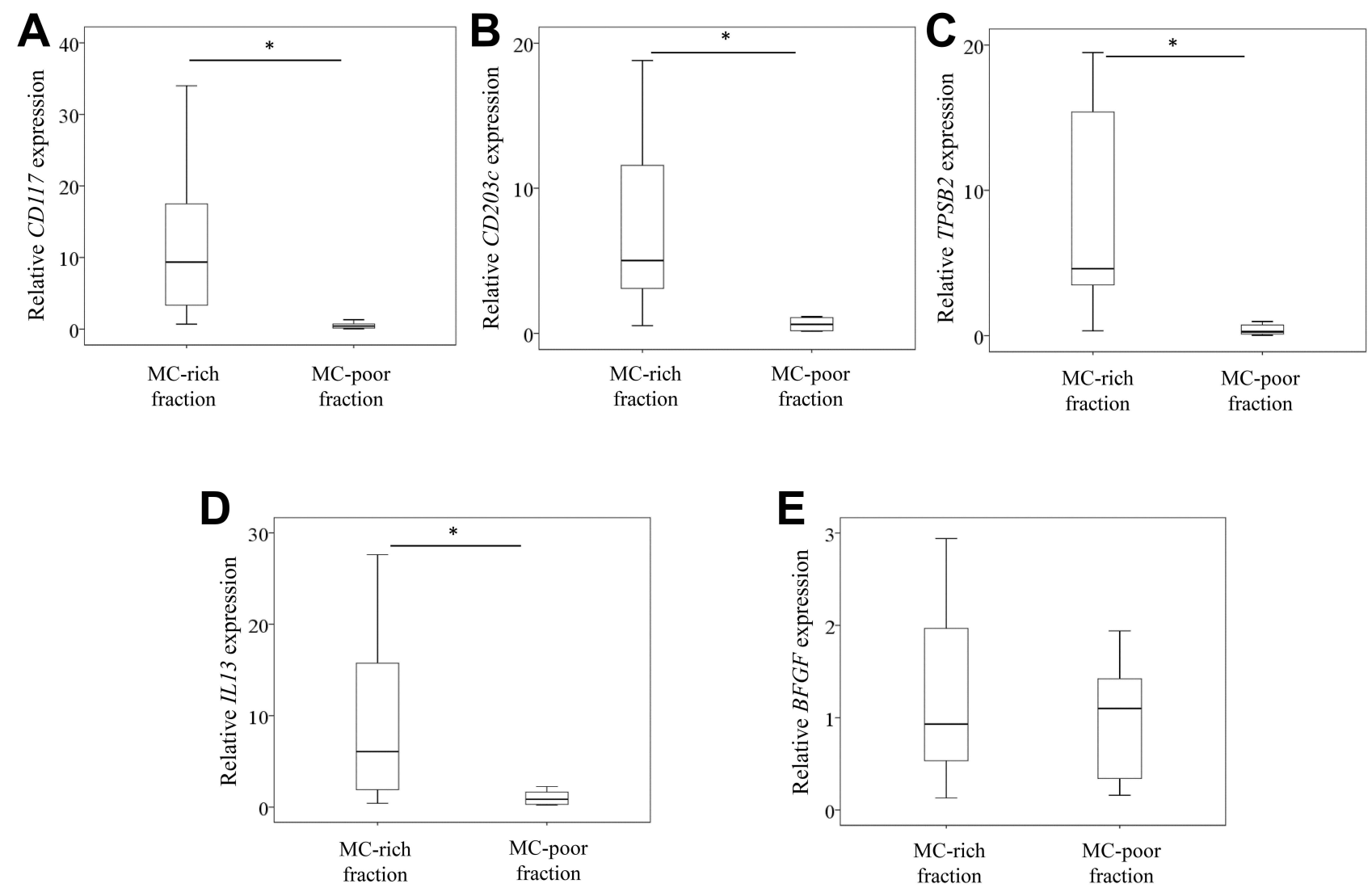

Figure 3 Expression of MC markers, BFGF and ILI 3 in mast cells. CDII 7 (A), CD203c (B), TPSB2 (C), ILI3 (D), and BFGF (E) expression levels in mast cell (MC)-rich (THYI-CD3-CDI4-CDI9-) and MC-poor (THY-I+, CD3+, CDI4+, or CDI9+) fractions. *P<0.05. P values are indicated.

\section{Effect of IL-I 3 on BFGF Expression in Synovial Fibroblasts and $M \varphi$}

Given that $B F G F$ expression was comparable between MCpoor and MC-rich fractions, we next studied the effect of rhIL13 on $B F G F$ expression in fibroblast- and $\mathrm{M} \varphi$-rich fractions isolated from the ST of KOA patients. Exposure to rh-IL13 induced $B F G F$ expression in synovial fibroblast-rich fractions
( $\mathrm{P}=0.043$; Figure 4A) but not $\mathrm{M} \varphi$-rich fractions $(\mathrm{P}=0.093$; Figure 4B) at $6 \mathrm{~h}$ following stimulation.

\section{Discussion}

Obesity alters local and systemic bFGF levels. Furthermore, high levels of plasma FGF2 have been shown to be correlated with fat mass in Han Chinese populations. ${ }^{23}$ In our previous

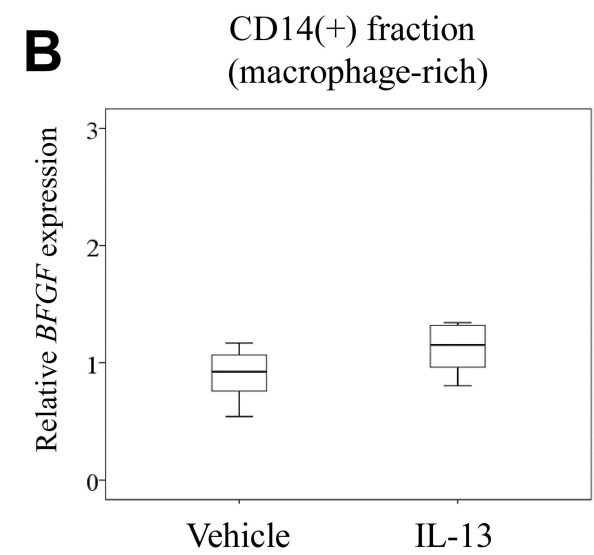

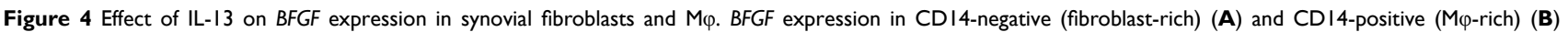
fractions at $6 \mathrm{~h}$ after stimulation with vehicle or IL-13. $* \mathrm{P}<0.05$. $\mathrm{P}$ values are indicated. 
study, we reported that KOA patients with obesity had higher expression of synovial bFGF and MC markers than normalweight patients with $\mathrm{OA}^{6}{ }^{6}$ Consistent with our previous results, we found that KOA patients with obesity had elevated $\mathrm{bFGF}$ and $\mathrm{MC}$ marker expression in the present study. Accumulating evidence indicates that bFGF contributes to OA pathology and cartilage destruction. bFGF stimulates the expression of MMP-13 expression in human articular chondrocytes. ${ }^{24}$ Thus, elevation of bFGF may contribute to OA pathology in KOA patients with obesity.

Immunohistochemical studies have reported increased bFGF staining in hyperplastic lining synoviocytes, and vascular cells in ST derived from rheumatoid arthritis patients. ${ }^{7}$ To investigate the potential role of MCs in bFGF expression, we measured bFGF expression in MCs isolated from osteoarthritic ST. However, we found no differences between $\mathrm{MC}$ and non-MC populations. Thus, although MCs express bFGF, whether MCs contribute to the elevation of bFGF in the osteoarthritic ST remains unclear.

Previous studies have reported that IL-13 is released by several immune cells including $\mathrm{T}$ cells, ${ }^{25} \mathrm{MCs},{ }^{15,26}$ eosinophils, ${ }^{27}$ and basophils. ${ }^{28}$ We found that MCs expressed higher IL-13 levels than non-MC populations. In addition, IL-13 stimulated $B F G F$ expression in synovial fibroblasts. Thus, increased MC numbers may induce $B F G F$ expression in OA pathology by activating synovial fibroblasts in KOA patients with obesity.

There were main two limitations in the present study. First, we lack data on non-OA patients. Second, we did not examine protein levels.

In conclusion, KOA patients with obesity showed higher BFGF expression than normal- and overweight patients. Increased $\mathrm{MC}$ numbers may contribute to the elevation of $B F G F$ expression through IL-13 in KOA patients with obesity.

\section{Acknowledgments}

This investigation was supported by Grant-in-Aid for Early-Career Scientists Grant No. 20K18073.

\section{Disclosure}

The authors report no conflicts of interest regarding this work.

\section{References}

1. Grotle M, Hagen KB, Natvig B, Dahl FA, Kvien TK. Obesity and osteoarthritis in knee, hip and/or hand: an epidemiological study in the general population with 10 years follow-up. BMC Musculoskelet Disord. 2008;9:132. doi:10.1186/1471-2474-9-132
2. Oliveria SA, Felson DT, Cirillo PA, Reed JI, Walker AM. Body weight, body mass index, and incident symptomatic osteoarthritis of the hand, hip, and knee. Epidemiology. 1999;10(2):161-166. doi:10.1097/00001648-199903000-00013

3. Im HJ, Muddasani P, Natarajan V, et al. Basic fibroblast growth factor stimulateSTatrix metalloproteinase-13 via the molecular cross-talk between the mitogen-activated protein kinases and protein kinase Cdelta pathways in human adult articular chondrocytes. $J$ Biol Chem. 2007;282(15):11110-11121. doi:10.1074/jbc.M609040200

4. Li X, Ellman MB, Kroin JS, et al. Species-specific biological effects of FGF-2 in articular cartilage: implication for distinct roles within the FGF receptor family. $J$ Cell Biochem. 2012;113(7):2532-2542. doi: $10.1002 /$ jcb. 24129

5. Honsawek S, Yuktanandana P, Tanavalee A, Saetan N, Anomasiri W, Parkpian V. Correlation between plaSTa and synovial fluid basic fibroblast growth factor with radiographic severity in primary knee osteoarthritis. Int Orthop. 2012;36(5):981-985. doi:10.1007/s00264011-1435-z

6. Uchida $\mathrm{K}$, Takano $\mathrm{S}$, Inoue $\mathrm{G}$, et al. Increase in mast cell marker expression in the synovium of obese patients with osteoarthritis of the knee. DiabeteSTetab Syndr Obes. 2019;12:377-382. doi:10.2147/ DMSO.S201523

7. Ramirez J, Celis R, Usategui A, et al. Immunopathologic characterization of ultrasound-defined synovitis in rheumatoid arthritis patients in clinical remission. Arthritis Res Ther. 2016;18:74. doi:10.1186/ s13075-016-0970-9

8. Rivellese F, Rossi FW, Galdiero MR, Pitzalis C, de Paulis A. Mast Cells in Early Rheumatoid Arthritis. Int J Mol Sci. 2019;20(8):2040. doi:10.3390/ijms20082040

9. Buckley MG, Gallagher PJ, Walls AF. Mast cell subpopulations in the synovial tissue of patients with osteoarthritis: selective increase in numbers of tryptase-positive, chymase-negative mast cells. J Pathol. 1998;186(1):67-74. doi:10.1002/(SICI)1096-9896(199809) 186:1<67::AID-PATH132>3.0.CO;2-D

10. de Lange-brokaar BJ, Kloppenburg $\mathrm{M}$, Andersen $\mathrm{SN}$, et al. Characterization of synovial mast cells in knee osteoarthritis: association with clinical parameters. Osteoarthritis Cartilage. 2016;24 (4):664-671. doi:10.1016/j.joca.2015.11.011

11. Dean G, Hoyland JA, Denton J, Donn RP, Freemont AJ. Mast cells in the synovium and synovial fluid in osteoarthritis. $\mathrm{Br} J$ Rheumatol. 1993;32(8):671-675. doi:10.1093/rheumatology/32.8.671

12. Inoue Y, King TE, Tinkle SS, Dockstader K, Newman LS. Human mast cell basic fibroblast growth factor in pulmonary fibrotic disorders. Am J Pathol. 1996;149(6):2037-2054.

13. Qu Z, Liebler JM, Power STR, et al. Mast cells are a major source of basic fibroblast growth factor in chronic inflammation and cutaneous hemangioma. Am J Pathol. 1995;147(3):564-573.

14. Cameron L, Hamid Q, Wright E, et al. Local synthesis of epsilon germline gene transcripts, IL-4, and IL-13 in allergic nasal mucosa after ex vivo allergen exposure. J Allergy Clin Immunol. 2000;106(1 Pt 1):46-52. doi:10.1067/mai.2000.107398

15. McLeod JJ, Baker B, Ryan JJ. Mast cell production and response to IL-4 and IL-13. Cytokine. 2015;75(1):57-61. doi:10.1016/j. cyto.2015.05.019

16. Pawankar R, Okuda M, Yssel H, Okumura K, Ra C. Nasal mast cells in perennial allergic rhinitics exhibit increased expression of the $\mathrm{Fc}$ epsilonRI, CD40L, IL-4, and IL-13, and can induce IgE synthesis in B cells. J Clin Invest. 1997;99(7):1492-1499. doi:10.1172/JCI119311

17. Isomaki P, Luukkainen R, Toivanen P, Punnonen J. The presence of interleukin-13 in rheumatoid synovium and its antiinflammatory effects on synovial fluid $\mathrm{M} \varphi$ from patients with rheumatoid arthritis. Arthritis Rheum. 1996;39(10):1693-1702. doi:10.1002/ art.1780391012

18. Moue T, Tajika Y, Ishikawa S, et al. Influence of IL13 on Periostin Secretion by Synoviocytes in Osteoarthritis. Vivo. 2017;31(1):79-85. doi:10.21873/invivo.11028 
19. Nees TA, Rosshirt N, Zhang JA, et al. Synovial Cytokines Significantly Correlate with Osteoarthritis-Related Knee Pain and Disability: inflammatory Mediators of Potential Clinical Relevance. J Clin Med. 2019;8(9):1343. doi:10.3390/jcm8091343

20. Lee JH, Kaminski N, Dolganov G, et al. Interleukin-13 induces dramatically different transcriptional programs in three human airway cell types. Am J Respir Cell Mol Biol. 2001;25(4):474-485. doi:10.1165/ajrcmb.25.4.4522

21. Noordenbos T, Yeremenko N, Gofita I, et al. Interleukin-17-positive mast cells contribute to synovial inflammation in spondylarthritis. Arthritis Rheum. 2012;64(1):99-109. doi:10.1002/art.33396

22. Takano S, Uchida K, Miyagi M, et al. Nerve Growth Factor Regulation by TNF-alpha and IL-1beta in Synovial M $\varphi$ and Fibroblasts in Osteoarthritic Mice. $J$ Immunol Res 2016;2016:5706359. doi:10.1155/2016/5706359

23. Hao RH, Guo Y, Dong SS, et al. Associations of PlaSTa FGF2 Levels and PolymorphiSTs in the FGF2 Gene with Obesity Phenotypes in Han Chinese Population. Sci Rep. 2016;6:19868. doi:10.1038/ srep 19868
24. Im HJ, Sharrocks AD, Lin X, et al. Basic fibroblast growth factor induceSTatrix metalloproteinase-13 via ERK MAP kinase-altered phosphorylation and sumoylation of Elk-1 in human adult articular chondrocytes. Open Access Rheumatol. 2009;1:151-161. doi:10.21 47/oarrr.s 7527

25. Corry DB. IL-13 in allergy: home at last. Curr Opin Immunol. 1999;11(6):610-614

26. Burd PR, Thompson WC, Max EE, Mills FC. Activated mast cells produce interleukin 13. J Exp Med. 1995;181(4):1373-1380. doi:10.1084/jem.181.4.1373

27. Schmid-Grendelmeier P, Altznauer F, Fischer B, et al. Eosinophils express functional IL-13 in eosinophilic inflammatory diseases. J Immunol. 2002;169(2):1021-1027. doi:10.4049/jimmunol.169.2. 1021

28. Li H, Sim TC, Alam R. IL-13 released by and localized in human basophils. J Immunol. 1996;156(12):4833-4838.

Diabetes, Metabolic Syndrome and Obesity: Targets and Therapy

Dovepress

\section{Publish your work in this journal}

Diabetes, Metabolic Syndrome and Obesity: Targets and Therapy is an international, peer-reviewed open-access journal committed to the rapid publication of the latest laboratory and clinical findings in the fields of diabetes, metabolic syndrome and obesity research. Original research, review, case reports, hypothesis formation, expert opinion and commentaries are all considered for publication. The manuscript management system is completely online and includes a very quick and fair peer-review system, which is all easy to use. Visit http://www.dovepress.com/testimonials.php to read real quotes from published authors.

Submit your manuscript here: https://www.dovepress.com/diabetes-metabolic-syndrome-and-obesity-targets-and-therapy-journal 